\title{
Global Jewish Philanthropy and Linguistic Pragmatism in Baghdad
}

\author{
Sasha R. Goldstein-Sabbah
}

The Jewish community of Baghdad changed dramatically from the midnineteenth century until its dissolution between 1949 and 1951. These changes were due to political, social, and technological factors which influenced the entirety of Iraqi society. For the Jewish community of Baghdad, whose numbers went from 24,000 in $1876^{1}$ to 118,000 in $1947,{ }^{2}$ these changes meant that in less than a century the Jews in Baghdad saw the emergence of a flourishing, multi-lingual educated middle class who was actively engaged in Iraqi society and yet deeply connected to world Jewry. ${ }^{3}$ One important factor in this communal transformation was the role of foreign actors and in particular foreign Jewish philanthropic organizations. This chapter explores the importance of transnational Jewish solidarity in Baghdad and what can be learned about the Jewish communal leadership of Baghdad during this period via their exchanges with European Jews. My central argument is that collaboration with foreign Jewish groups was a constant theme between 1860 to 1950 that ultimately gave the Jewish community relevance within the wider Iraqi society during the Hashemite period. Furthermore, I hope to demonstrate that philanthropic partnerships were established based on considerations of linguistic pragmatism, political landscape and economic implications.

Foreign Jewish aid, from both organizations and individuals, played an immeasurable role in this development, without which the community would not have been able to flourish as it did. Although the financial aspect of this aid was central to communal development, help also came in other forms that were just as instrumental, specifically by providing technical expertise and political support. These organizations were, in large part, responsible for the importation of Western culture and European language instruction to the Jewish

1 Maurice M. Sawdayee, The Baghdad Connection (Locust Valley, NY: Maurice M. Sawdayee, 1991), 17 [citing Jacob Obermayer in Ha-Magid, 12 January 1876].

2 Hana Battatu, The Old Social Classes and the Revolutionary Movement of Iraq: A Study of Iraq's Old Landed and Commercial Classes and of its Communists, Ba'thists, and Free Officers (Princeton, NJ: Princeton University Press, 1978), 40.

3 Abbas Shiblak, Iraqi Jews: A History of Mass Exodus (London: Saqi Books, 2005), 33-54.

(C) SASHA R. GOLDSTEIN-SABBAH, 2020 | DOI:10.1163/9789004423220_009

This is an open access chapter distributed under the terms of the CC BY-NC 4.0 license in-Sabbah - 9789004423220 
community of Baghdad. ${ }^{4}$ The languages used by the community both for written and spoken interaction significantly diversified. Whereas in the midnineteenth century the Jews of Baghdad primarily spoke a local dialect often referred to as Judeo-Baghdadi, ${ }^{5}$ and wrote in Judeo-Arabic (Arabic language in Hebrew script), using Hebrew for liturgical purposes and rabbinic correspondence, by the Mandate period most literate Baghdadi Jews were writing the Arabic language in Arabic script, and able to read and write in either French or English or both languages. Hebrew for the most part remained a liturgical language, although there are also examples of Modern Hebrew linguistic creativity during this period. ${ }^{6}$ As to spoken language, Judeo-Baghdadi remained the de facto communal language, although the local Muslim-Baghdadi Arabic dialect, English and French also became important languages of communication.

Studying the different types of aid provided by foreign Jewish philanthropic organizations in collaboration with the local communal leadership helps explain how the community could change so dramatically in a relatively short period. The analysis of this relationship also sheds light on the objectives of the Jewish communal leadership, and challenges notions that foreign benefactors rather than/opposed to local elites were the key decision makers in the development of the communal infrastructure. In this chapter I summarize some of the motivations behind transnational Jewish solidarity, and provide an overview of the history of the Alliance Israélite Universelle (AIU) and the Anglo-Jewish Association's (AJA) activities in Baghdad. By comparing and contrasting these two organizations we can gain greater insight into the political and linguistic choices made by the communal leadership during the mandate and early years of the Iraqi state. Finally, I will draw some conclusions about what these relationships teach us about the Jewish community of Baghdad and their language choices.

Thehistorical documents used for this chapter are primarily from the Alliance Israélite Universelle Archives in Paris, and the Anglo-Jewish Archives housed at the University of Southampton. These documents have been supplemented by secondary source material relating to the concept and history of transnational Jewish solidarity and Iraqi Jewish History, in particular Nora Şeni's Les inventeurs de la philanthropie juive and Matthias Lehmann's Emissaries from the Holy Land: The Sephardic Diaspora and the Practice of Pan-Judaism in the

4 Zvi Yehuda, "Iraqi Jewry and Cultural Change in the Educational Activity of the Alliance Israélite Universelle," in Harvey E. Goldberg (ed.), Sephardi and Middle Eastern Jewries: History and Culture in the Modern Era (Bloomington: Indiana University Press, 1996), 134-145.

5 Haim Blanc, Communal Dialects in Baghdad (Cambridge: Harvard University Press, 1964).

6 Lev Hakak, The Emergence of Modern Hebrew Creativity in Babylon, 1735-1950 (West Lafayette: Purdue University Press, 2009). 
Eighteenth Century. ${ }^{7}$ For the section on the role of the AIU I have greatly benefited from an article by Zvi Yehuda, "Iraqi Jewry and Cultural Change," which discusses the role of the AIU prior to the British Mandate. ${ }^{8}$ Although the histories of these two organizations in Iraq is each worthy of its own volume, my objective in this chapter is not to provide an exhaustive history of these organizations in Iraq, a project which still needs to be undertaken. Instead, I attempt to shed some light onto the history of Baghdadi Jewish cooperation with foreign Jewish philanthropic organizations, and explore what we can learn about the Jewish communal leadership in Baghdad from these relationships.

\section{Modernity, Transnational Jewish Solidarity, and Philanthropy}

With few exceptions, Jewish communities have rarely existed in isolation with no connections to other Jewish communities. For example, Baghdad had occasional Jewish visitors over the centuries, even after it ceased to be the centre of the Jewish exile in the eleventh century. Notably, Benjamin of Tudela in the twelfth century and Petahiah of Regensburg in the thirteenth century both wrote of their sojourns in the city and their impressions of the Jewish community. ${ }^{9}$ However, from the tenth to the nineteenth century Jewish communities around the globe were rarely in regular structural communication, either ecclesiastical or secular, as no overarching organization existed at the time. Instead, these connections were generally informal networks, both from a religious perspective with rabbis offering guidance in the form of responsa, or from an economic perspective with trade and banking networks linking communities (at times oceans apart). However, there is little historical evidence that these traditional connections translated themselves into the concept of a unified transnational Jewish community or the idea of a "Jewish people." Instead, in different periods communities of Jews practiced forms of transnational Jewish solidarity via different Jewish diaspora networks, often connected to charity. ${ }^{10}$

$7 \quad$ Nora Şeni, Les inventeurs de la philanthropie juive (Paris: Éditions de La Martinière, 2005); Matthias Lehmann's Emissaries from the Holy Land: The Sephardic Diaspora and the Practice of Pan-Judaism in the Eighteenth Century (Stanford: Stanford University Press, 2014).

8 Yehuda, "Iraqi Jewry," 134-145.

9 Yaron Ayalon, "Baghdad," in Norman A. Stillman (ed.), Encyclopedia of Jews in the Islamic World (Leiden: Brill, 2010) Vol. I, 313.

10 Lehmann, Emissaries from the Holy Land, 8-14. 
Prior to the nineteenth century transnational Jewish charity or philanthropic work was centred on the idea of halukka, ${ }^{11}$ whereby shlikhim would travel the Jewish world collecting funds to support religious charitable institutions and academies in Hebron, Tiberias, Safed and Jerusalem. ${ }^{12}$ And even this work was relatively limited because charity (sedaqa), although central to Judaism, was seen as a local obligation within one's own community. The religious obligation specifies three types of charity: to support orphans and widows; to provide food, clothes, and shelter to Jews visiting from other communities; and the remittance of funds to the Holy Land to support the pious Jews residing there. However, there was no historic precedence for Diaspora communities supporting other Diaspora communities prior to the middle of the nineteenth century, with occasional rare exceptions, for instance in the case of natural disasters, for example. However, even halukka was decentralized before the nineteenth century. Instead, different groups present in the Holy land competed for financial support by targeting the communities with which they had family links. ${ }^{13}$

As Nora Şeni notes in Les inventeurs de la philanthropie juive, the radical changes in the way Jewish communities approached charity and perceived their relationship to other Jewish communities were closely linked to the idea of the "age of modernity" as expressed by the European Enlightenment and the Haskala, modifying how European Jews viewed their relationship with and responsibilities towards Middle Eastern and North African Jews. ${ }^{14}$ One of the reasons European Jewish intellectuals took an interest in "Oriental Jewry" was their search for authentic Jewish practice, a newfound interest in Jewish history, and a general intellectual curiosity. In turn, they wrote about their findings in Haskala newspapers making European Jewry aware of the existence of

11 Halukka is the remitting of funds to Jerusalem (and other holy cities) to support small, usually impoverished, communities of religious Jews. Examples of this practice appear in documents found in the Cairo Geniza, although the practice is most likely much older.

12 The history of emissaries to Israel was compiled by Abraham Yacari in 1951. Although Ya'ari's attempt to show an uninterrupted connection between the Jewish people with the land of Israel and a historic Jewish unity has been highly criticized, his history of shlikhim remains the reference on topic. Abraham Ya'ari, Sheluhei Erets Yisra'el (Jerusalem, 1951). For criticism on Ya'ari's work see Jacob Katz, "He'arot sotsyologiyot le-sefer histori," Behinot 2 (1952) as cited in Lehmann, Emissaries from the Holy Land, 7-9.

13 Lehmann, Emissaries from the Holy Land, 11-14.

14 Şeni, Les inventeurs de la philanthropie juive. For a wider discussion on the Haskalah see Moshe Pelli, Haskalah and Beyond: The Reception of the Hebrew Enlightenment and the Emergence of Haskalah Judaism (Lanham: University Press of America, 2010), 16. 
these other Jewish communities. ${ }^{15}$ Additionally, with the rise of modern journalism, news of events such as the Damascus affair of 1840, the Mortara Affair in 1860 , and anti-Jewish riots reached European Jews relatively quickly. ${ }^{16}$ These events were of great concern to 'enlightened' European Jews such as James de Rothschild, Moses Montefiore and Adolph Cremieux, who felt an obligation to help their co-religionists. Thus, these 'emancipated Jews' laid the foundations of not only modern Jewish philanthropy, but consequently also of modern international Jewish solidarity, through the founding of organizations dedicated to the plights of Middle Eastern and North African Jewry. In Baghdad the two most important of these organizations were the French Alliance Israélite Universelle (AIU) founded in 1860, and the English Anglo-Jewish Association (AJA) founded in $1871 .{ }^{17}$

There are several important differences between the pan-Jewish aid networks of the eighteenth century that Lehmann writes about, and the transnational Jewish philanthropic networks of the nineteenth century that Şeni discusses. Firstly, the eighteenth-century networks were exclusively focused on helping the Jews in the Land of Israel and thus looked only to other Jewish communities outside of Palestine as potential donors. Secondly, the eighteenth-century networks were organized by Jewish subgroups, the most active of which were the Sephardic Jewish networks. ${ }^{18}$ Thus, one major change in the nineteenthcentury Jewish philanthropic networks was the rapprochement between different Jewish subgroups, and the fact that these associations organized themselves along national lines rather than religious traditions. ${ }^{19}$ Thirdly, the eighteenth-century networks were relatively conservative in their objectives, aiming to assist the impoverished in times of crisis, whereas the nineteenthcentury philanthropic networks aimed to "westernize," "modernize," "improve"

15 Orit Bashkin, "Why did Baghdadi Jews Stop writing to their brethren in Mainz?," in Histories of Printing and Publishing in the Languages and Countries of the Middle East, edited by Philip Sadgrove, Journal of Semitic Studies Supplement 15 (2005): 108-109.

16 Jonathan Frankel, The Damascus Affair: 'Ritual Murder,' Politics, and the Jews in 1840 (Cambridge: Cambridge University Press, 1997).

17 The American Joint Jewish Distribution Committee and the Hilfsverein der deutschen Juden were also active in Baghdad during this time. However, their contribution to the development of infrastructure was significantly smaller, and therefore I have not addressed them in this chapter.

18 Lehmann, Emissaries from the Holy Land, 4-5.

19 This is apparent in all Jewish philanthropic organisations in which the leadership represented a mixture of both Ashkenazi and Sephardic Jews (in the case of the AIU and AJA), and a mixture of Ashkenazi Jews with Eastern and Western European origins (in the case of the JDC). 
and "civilize" the communities they were aiding. ${ }^{20}$ Finally, the organizations of the nineteenth century had strict hierarchies, a bureaucratic apparatus, and a defined ideology - a marked difference from the dynamic networks of the eighteenth century. ${ }^{21}$

Returning to Baghdad: in the mid-nineteenth century the city was a relative backwater in the Ottoman Empire, with little public infrastructure, no printed newspapers in the city, and no secular education options. This was in sharp contrast to European Jewry, who had already undergone over a century of transformation via the ideals of the Enlightenment, the industrial revolution, and the Haskala. With the arrival of European Jews and their newspapers in Baghdad the literate Jews of the city were more connected with other Jewish communities than in the preceding decades. Thus, they became aware of the debates among European Jewry, particularly those on the secularization of education and the adoption of certain Western cultural norms. Although not officially organized until the founding of the lay council in 1879, from as early as the 186 os Baghdadis Jews corresponded with European Jews, publicly (via the newspapers of the Haskala) as well as privately, imploring their brethren in Europe to help the communal elites to modernize their community through various forms of aid and support. ${ }^{22}$ In addition to these newfound connections, over the course of the nineteenth century an important Baghdadi Diaspora developed in the British colonies of India and East Asia. These communities were extremely successful commercially, and developed strong economic, political, and cultural ties with European Jewry while at the same time maintaining a connection to Baghdad. ${ }^{23}$ The result is that as part of their philanthropic

\footnotetext{
20 Lehmann, Emissaries from the Holy Land, 14.

21 Ibid., 11.

22 Bashkin, "Why did Baghdadi Jews," 108-109.

23 For more information about the "Eastern Baghdadi communities," see, for India, Joan Roland, The Jewish Communities of India: Identity in a Colonial Era (London: Transaction Publishers, 1998), and Ezekiel Musleah On the Banks of the Ganga: The Sojourn of Jews in Calcutta (North Quincy MA: The Christopher Publishing Company, 1975); for Singapore, Joan Bieder The Jews of Singapore (Singapore: Suntree, 2007); for Burma, Ruth Fredman Cernea, Almost Englishmen: Baghdadi Jews in British Burma (New York: Lexington Books, 2007), for China, Maisie J. Meyer, From the Rivers of Babylon to the Whangpoo: A Century of Sephardi Jewish Life in Shanghai (New York: University Press of American, 2003) and Chiara Betta, "From Orientals to Imagined Britons: Baghdadi Jews in Shanghai," Modern Asian Studies 37,4 (2003): 999-1023. http://www.jstor.org/stable/3876534. For a discussion of women in the Baghdadi Jewish Diaspora, Jael Silliman Jewish Portraits Indian Frames: Women's Narratives from a Diaspora of Hope (Lebanon: University Press of New England, 2001).
} 
initiatives in the city these wealthy Eastern Baghdadis pleaded with the AIU and AJA on behalf of Baghdad.

These changes in Baghdad, and the relationship between disparate Jewish communities at this particular moment in history, are part of a broader narrative of changes in the question of Jewish identity throughout the European and North American Jewish Diasporas during the nineteenth century. Specifically, this period marks the beginning of a transition from Jewish subgroups grounded in either a specific geographic location or specific religious customs (such as Sephardic, Maghrebi, or Eastern European Ashkenazi) towards the idea of a larger global Jewish people, in which many Jews began to imagine themselves as one unified community. ${ }^{24}$ This change was not limited to Baghdad or its communal leadership in the nineteenth century. Rather, it was a fundamental change in Jewish communal perception which occurred (and was also contested) throughout Europe, North America and the Middle East in different places and at different times throughout the nineteenth and twentieth centuries, arising from questions of nationalism and the concept of minority in the modern nation state. In the context of the Jewish community of Baghdad great attention is usually given to their integration into Iraqi society in the first half of the twentieth century, ${ }^{25}$ but it should not be forgotten that the Jewish community was strongly linked to world Jewry during this same period, a relationship that developed because of philanthropic ties. Therefore, different identities were being developed parallel to each other, although none of these were mutually exclusive. With the rise of Arab nationalism and the growing tension over the Palestine question, the foreign Jewish ties of the Jewish community in Baghdad became more complicated and monitored but were never severed by either side.

The philanthropic relationship between Baghdad as the receiver of aid from the Baghdadi Jewish Diaspora on the one hand, and the foreign Jewish philanthropic organizations on the other, were central to the development of the communal infrastructure. Cooperation with foreign Jewish philanthropic organisations brought Baghdadi Jews of all social levels into contact with other Jewish groups through these new schools, hospitals, and charities. The Jews of Baghdad received multiple forms of aid, in three areas - financial aid, sharing of knowledge, and political assistance. Financial aid is the most quantifiable form of support. Regular donations, special grants from foreign organizations,

\footnotetext{
24 Lehmann, Emissaries from the Holy Land, 1-14.

25 Orit Bashkin, New Babylonians: A History of Jews in Modern Iraq (Stanford: Stanford University Press, 2012), Aline Schlaepfer, Les intellectuels juifs de Bagdad: Discours et allégeances (1908-1951), Christians and Jews in Muslim Societies series (Leiden: Brill, 2016).
} 
and assistance in facilitating donations from individuals in foreign Jewish communities all helped to establish the successful network of social institutions developed and managed by the communal leadership. Although the European Jewish philanthropic organizations provided some money for education, they were not the primary benefactors. ${ }^{26}$ The main providers of financial assistance were the wealthy Jews inside Iraq such as Menahem Daniel Saleh, wealthy Baghdadi Jews residing outside Iraq such as the Sassoon and Kadoorie families, and foreign Jewish philanthropic aid organizations. The Jewish community was also successful in occasionally acquiring funds from foreign consuls wishing to expand their spheres of influence in Baghdad, specifically through the study of English and French or by providing scholarships for study abroad. ${ }^{27}$

Besides financial support one of the most important functions of these organizations was assistance in providing, or arranging for, experts to travel to Baghdad to advise the community. As Peter Sluglett mentions, due to an underdeveloped education system there was a general dearth of educated individuals in Iraq well into the 1930s, and specifically of teachers capable of teaching Western languages. ${ }^{28}$ However, the Jewish community was able to utilize their international connections to recruit foreign teachers, administrators, doctors, nurses, and other experts who were sent by foreign Jewish organizations to either work in Baghdad themselves, or to train locals from the Baghdad community in areas where expertise was lacking. Aid organizations arranged for Jewish students to receive training in France, England, and even the United States, on condition that they return to their home country or to another country in need of teachers to teach afterwards. ${ }^{29}$

Finally, the most sensitive form of aid provided by the Jewish philanthropic organizations was that of assuming the function of political lobbyist, informant, negotiator and at times protector, because it had the potential to raise questions of dual loyalties. Although the role of political negotiator began in the nineteenth century, this form of aid was to gain greater importance with the dissolution of the Ottoman Empire as the importance of Britain in Iraq grew. Very wealthy Baghdadis abroad also played an important role in lobbying

26 Jewish schools report 1925 MS 137 AJ37/4/5, Jewish schools reports 1930 CAHJP Iraq File $\mathrm{P}_{3} / 2464$.

$27 \quad \mathrm{CO} 730 / 177 / 2$.

28 Peter Sluglett, Britain in Iraq: Contriving King and Country (London: I.B. Tauris, 2017), 193-209.

29 MS $137 \mathrm{AJ} 37 / 4 / 5$ - These documents are about Baghdadi students sent to study in London but refusing to return to Iraq to teach as per their agreement. Of particular interest are the files between 1940-1942. 
for the community, liaising with foreign governmental bodies on behalf of the Jewish community of Baghdad. This role as political agent and advisor is the most complicated of the three types of aid provided to the community, because these political 'links' aroused questions of conflicting loyalties, especially when anti-British sentiments in Iraq grew during the post-Mandate period. This issue of political support is further complicated by the fact that many of these Jewish organizations helping the Jewish community in Baghdad also had strong ties to the Jewish community in Palestine. However, these important political connections persisted up until the dissolution of the community.

In conclusion, assistance came in many formats that went well beyond financial aid. Furthermore, foreign Jewish philanthropic organizations were not the only actors outside Baghdad to provide aid to the Jewish community: foreign governments and the Baghdadi Jewish Diaspora were also active parts of this complex network of aid, thus reaffirming the intricate networks which existed between the Jewish community of Baghdad and other organizations and groups.

Foreign Consuls and Jewish Philanthropic Organizations

On the eve of the British Mandate, the lay council's ${ }^{30}$ main focus was on developing a network of secular schools, charities, and hospitals to accommodate the Jewish population of the city, a process which had begun in the nineteenth century. ${ }^{31}$ To achieve these goals the lay council actively worked to strengthen its ties to French and English consuls, with whom the French Alliance Israélite Universelle (AIU), and the English Anglo-Jewish Association (AJA) were in constant contact. ${ }^{32}$ By exploring the relationships between these

30 The lay council was the secular council that governed the activities of the Jewish community, controlled its budget, and acted as the government-recognized spokesperson for the Jewish community in Baghdad. The council was established in 1879 as part of the Ottoman Tanzimat reforms and continued to function during the British Mandate and the period of the Iraqi Republic, see Eliyahu Agassi and Avraham Ben-Yaakov, "Chapter Nine: Communal Administration and Institutions," in Ora Melamed (ed.), Annals of Iraqi Jewry (Jerusalem: Eliner Library, 1995).

31 Yehuda, "Iraqi Jewry," 134-145.

32 The American Joint Jewish Distribution Committee (JDC) was also active in Baghdad during this time. Their contribution to the development of infrastructure was significantly smaller than the AIU and AJA and therefore I have not addressed them in this chapter. For more information about the JDC, see Sasha Rachel Goldstein-Sabbah, "Baghdadi Jewish Networks in Hashemite Iraq: Jewish Transnationalism in the Age of Nationalism" (PhD diss., Leiden University, 2019). 
organizations and both the Jewish community in Baghdad and their local governmental representatives we may begin to understand how the Jewish community of Baghdad negotiated various state and non-state actors in the first half of the twentieth century. Unlike the Baghdadi Jews residing on the Indian subcontinent and in East Asia, these organizations did not have a special connection to Baghdad. Although these European Jews may have felt a spiritual or moral connection to the Jews in Baghdad, in reality they knew very little about the community and often much of their information came via the consuls of their respective countries, or from Eastern Baghdadis active in the organizations. For these aid organizations the Jewish community in Baghdad represented one community amongst the many they were trying to help across Eastern Europe, North Africa, and the Middle East as part of this new idea of transnational Jewish solidarity. In the overall landscape of Middle Eastern and North African Jewry, the Jews in Baghdad were wealthier than many other communities, due to their importance in the Iraqi economy, and as such it was assumed that they had greater internal means than other Jewish communities. For this reason, support from the local consuls and especially Eastern Baghdadis who acted as bridges between the local Baghdad community and the philanthropic organizations was essential.

From an administrative perspective, both organizations relied heavily on their local governmental representatives in Baghdad, such as the consulgeneral or other members of the civil administration. The Jewish elites in Baghdad, for their part, actively courted the American, French and British diplomatic missions in Baghdad; they saw the benefits these connections could have regarding all forms of aid, including matchmaking between the Jewish community of Baghdad and foreign Jewish organizations. ${ }^{33}$ These foreign delegations in turn often acted as an intermediary between Baghdad and foreign Jewish communities, making introductions and assuring the organizations that their resources were put to good use. The foreign diplomatic delegations themselves were also known for providing scholarships and other types of support, particularly to promote secular education within the Jewish communal schools. $^{34}$

33 Although not discussed in this chapter, the American Jewish Joint Distribution Committee (JDC) began to remit funds to the Jewish community of Baghdad because of a letter sent by Oscar S. Heizer, then US Consul in Baghdad to the JDC, suggesting they aided the community. JDC ARCHIVES - http://search.archives.jdc.org/multimedia/Documents/ NY_AR1921/ooo16/NY_AR1921_oo773.pdf

34 The British government gave small donations to the English Language Shamash School in the 1930s and 1940s. The French government provided scholarships for students to study 
An example of the Jewish community courting these foreign diplomats is an event in 1918, when the Jewish community of Baghdad hosted a fundraiser to provide general relief to the poor of all confessions in Mosul. This event took place at a liminal period in Iraqi history, at the tail end of the Ottoman Empire and the dawn of Iraqi statehood under British mandate. The event took place only one month after the lay council (unsuccessfully) petitioned the British Civil Commissioner in Baghdad to bestow British citizenship to the Jews of Baghdad. ${ }^{35} \mathrm{~A}$ British consular report about the event describes Jewish communal elites actively courting both Jewish and non-Jewish foreigners by presenting their own communal values as analogous to those of the foreign guests. Below is an excerpt from a report by the British India Office:

On the 1oth October Jewish Community entertained to dinner several members of America relief commission, the US consul, French consul, and several officers of Civil Administration (UK) [sic].

After dinner followed songs and recitations by Jewish school children exceedingly well done with several speeches by leading Jews in English and Arabic highly flattering to the present regime. As an expression of their earnest feelings the speeches were followed by an auction of some jewellery [sic], presented by a Jewish lady, for charitable purposes: the auction realized some Rs. 30,00o, Jewish ladies present spontaneously made further offers of jewelry.

At the close of evening it was announced that proceeds would with the permission of G.O.C. in chief be devoted to relief of poor in Mosul without distinction of creed wherever that place was??? [sic] ${ }^{36}$ either before or after end [sic] of war. My American friends found above entertainment very instructive. ${ }^{37}$

In this instance, the Jewish community was entertaining the three main foreign presences in Baghdad relevant to the Jewish community. Most likely these events were an opportunity for the Jews to present themselves as a modern

in Paris. See Naim Kattan, Farewell Babylon: Coming of Age in Jewish Baghdad (London: Souvenirs Press, 2005), 211.

35 Norman A. Stillman, Jews of Arab Lands in Modern Times (Philadelphia: JPS, 1991), $256-257$.

36 This is a direct transcription of the original letter. The writer is apparently not aware of the location of Mosul.

37 Indian Office Library, British Library IOR/L/PS/11/139 P 4484/1918. 
Westernized community, with values in line with the foreign countries represented. It is also likely that those in attendance were trying to position themselves as allies to these representatives, who were often navigating unfamiliar terrain with respect to culture, languages and politics. As the report notes, this event included educated children, community leaders who spoke English and Arabic, Jewish women publicly mingling with men, and a non-confessional philanthropic action, all of which were exceptional for Baghdad in 1918. This is analogous to the position taken by communal leadership and Eastern Baghdadis when corresponding with Jewish philanthropic organizations. This particular report was sent to the UK foreign office. They in turn were known to forward similar reports to the AJA, and it is probable that reports on this event made it into the hands of the AIU and the JDC, because similar-style reports exist in both organizations' archives. ${ }^{38}$

Beyond general reports on the state of the Jewish community in Baghdad, all Jewish philanthropic organizations used their local governmental representatives to oversee the distributions of these funds, representatives who at times went as far as to collect receipts from the lay committee or the schools' committee and sending these back to the organizations - a testament to the highly nationalist nature (British and French) or these organizations. ${ }^{39}$ Additionally, representatives of the local government often attended events organized by the schools on behalf of the organizations, sending back reports to attest to the level and quality of education and also to confirm that the financial aid had been put to good use. Thus, the relationship between the foreign Jewish organizations and the local diplomatic representation was effective in forging relationships between the local Jewish community and foreign governments.

Beyond these similarities in the working of each organization there were also differences. As I will describe in more detail below, the AIU's focus was mostly on providing expertise in the development of schools by supplying teachers, and educational material; its financial contributions were almost exclusively intended to support the AIU schools. The AJA, particularly during

38 For a detailed example of this with references to archival documents see Sasha Goldstein-Sabbah, "Censorship and the Jews of Baghdad: Reading between the lines in the case of E. Levy," The Journal of the Middle East and Africa 7:3 (2016): 283-300 (DOI: 10.1080/21520844.2016.1227927).

39 Yehuda Bauer, My Brother's Keeper: A history of the American Joint Distribution Committee 1929-1939, (Philadelphia: Jewish Publication Society of America, 1974), 15-17; JDC Archives: http://search.archives.jdc.org/multimedia/Documents/NY_AR1418/00003/NY_ AR1418_03503.pdf\#search='mesopotamia' JDC Archives 1917. This later changed as international banking became more reliable, and many of the financial transactions in the 1930 and 1940s would go through banks such as the East Bank or Bank Zilkha, many of whose executives also held positions within the Jewish communal administration. 
the Mandate, was to be a more active partner of the community, acting as an earpiece to both the British and Iraqi governments for the Jewish community; this in addition to helping to raise money from Jews in the UK to support the Jewish Institutions in Baghdad, and being instrumental in the overhauling of the Jewish schools in the 1920 .

The AIU was founded in Paris in 1860 as an outgrowth of Jewish emancipation in France and out of a desire to defend the rights of Jews within France as French citizens. Although the AIU would come to be known for its Jewish schools outside France, its initial goal was not to import 'Western Civilization' to the Jews of North Africa and the Middle East through the opening of schools. Instead, the initial aim was more local, i.e., to help French Jews who had not yet benefited from the economic and social opportunities that the founders of the AIU had been fortunate enough to receive through emancipation. The AIU looked to Judaism as moral guide that would "mettre d'accord dans l'homme, la foi, la raison, et le Coeur" in the modern secular emancipated world. ${ }^{40}$ As I already mentioned, the idea of extra-territorial Jewish solidarity was born out of concern in the wake of such incidents as the Damascus affair and other acts of violence against Jews in the world. ${ }^{41}$ This in turn led to education outside the French borders quickly becoming one of the AIU's main activities and its most enduring legacy. In working with Jewish communities abroad the AIU saw itself as a partner in development, providing resources and the expertise to successfully run a modern secular school. It demanded both financial and intellectual collaboration with the Jewish community (or members of it) for which it was opening a school. ${ }^{42}$

Baghdad was one the first cities in which an AIU school was opened. The original request for a secular Jewish school predates the formation of the lay council by fifteen years and was thus a private rather than a communal initiative. Two European Jews residing in Baghdad, Isaac Luria (a Russian watchmaker) and Herman Tzvi Rosenfeld (a German tailor), together with two

$40 \quad$ Perrine Simon-Nahumi, "Aux origines de l'Alliance," in Histoire de l'Alliance israélite universelle: de 1860 à nos jours, edited by André Kaspi (Paris: Armand Colin, 2010), 11-52.

41 Frankel, The Damascus Affair; Abigail Green and Vincent Viaene, eds, Religious Internationals in the Modern World: Globalization and Faith Communities since 1750 (Basingstoke: Palgrave Macmillan, 2012).

42 Aron Rodrigue, "La mission éducative (1860-1939)," in Histoire de l'Alliance israélite universelle: de 1860 à nos jours, edited by André Kaspi (Paris: Armand Colin, 2010), 227-228. 
Baghdad-born Jews, Joseph Shemtob and David Somekh, wrote to Paris, stating their desire to help the Baghdadi community form a school that would instruct boys in secular subjects and asking the AIU for help in this endeavour. The letter notes that they are aware of the school that had recently been opened for Jewish boys in Tetouan, Morocco and that they believe something similar would be ideal for the Jewish community of Baghdad. The letter also states that the members of the Jewish Baghdadi community had pledged money to support the school. ${ }^{43}$ On 10 December 1864 the Alliance school opened with Isaac Luria as its first director. ${ }^{44}$ This early initiative in secular education completely sidestepped the religious elites of the city, but was well received by those who saw the value in sending their sons to a secular school. By January 1865 the school had 43 students, and 75 by June of that year. ${ }^{45}$ The school's initial objective was to teach both secular and religious subjects, thus making it a direct rival to the Midrash Talmud Torah, the only other option for Jews wishing to obtain higher education in Baghdad.

The conflict between secular and religious elites is illustrated by a letter sent by the students of the AIU school to the French Consul in Baghdad in 1869, three years after the original school was opened. ${ }^{46}$ In this letter the students explain that the Rabbinate is falsely accusing them of "irreligion" and threatening excommunication. Therefore, they are writing to request help and protection from the French Consul, to defend their right to a secular education and prevent the school from being closed. This anecdote is indicative of the power struggle that went on between the religious and secular elites in Baghdad during the late nineteenth century. It is interesting to note that students were writing to the French consul, which would lead one to assume that the students believed the French consul would have power in assuaging concerns on the part of the Rabbinate. This was perhaps due to the students' own AIU education with its strong French nationalist bent. However, the students were wrong and the school was temporarily closed, largely due to pressure from the Rabbinate. Although this first experience with a secular AIU school was relatively short-lived, the school eventually re-opened. In 1879 Baghdad created a Jewish lay council, at which time a formal relationship between the Baghdadi Jewish elites and the AIU was established. ${ }^{47}$ Because most of the communication regarding the schools went via the Consul General de

\footnotetext{
43 Sawdayee, "The Baghdad Connection," 20.

44 Ibid., 20.

45 Ibid., 20; Bulletin de l'Alliance 1864, 4

46 AIU archives Bobin 4 fiche 8-9.

47 Yehuda, "Iraqi Jewry," 134-145.
} 
France, this relationship helped strengthen Jewish communal relations with the French administrative presence in Baghdad as they were in regular contact over the schools on behalf of the AIU. The relationship with the AIU in Paris remained detached, because the vast majority of teachers and school directors did not come from France but were instead AIU-educated Jews from other places in the Middle East and North Africa (MENA); this also fostered a sense of community between Baghdad and other Jewish communities in the region.

Overall the relationship between the AIU and the Jewish community in Baghdad was fraught with tension. ${ }^{48}$ The Jewish communal leadership was happy to accept the expertise, money, and political support of the AIU because they were committed to secular education, an objective that would have been difficult without AIU assistance. However, Iraqi elites were sceptical of the French cultural superiority that the AIU professed, and questioned whether a French-language as opposed to an English-language orientation was the most appropriate for the youngsters of the community. ${ }^{49}$ As early as 1872 , members of the Jewish community were pressuring the AIU to modify their standard curriculum. The suggestions for curriculum modification included an increase in the amount of time dedicated to Arabic and Hebrew, and the idea to possibly change the language of instruction to English. ${ }^{50}$ Although the AIU never fully acquiesced to these requests, these pressures did lead to some curriculum modification at the AIU schools, and reflect the high level of agency and engagement in these schools that came directly from Baghdadi communal leaders.

Until World War I the AIU remained the most active foreign Jewish organization in Baghdad, opening the two largest Jewish schools prior to the Mandate period: the Albert Sassoon boys' schools and the Laura Kadoorie girls' school. Each was named after the wealthy Eastern Baghdadi benefactor who had donated the land for the building of the school and set up endowments which would partially defray the school's operating expenses. Additionally, the AIU would set up other schools in partnership with the lay council utilizing the AIU curriculum although they received less financial and teaching support than the schools mentioned above. The success of these schools in the period prior to the Mandate meant that there was a strong francophone influence on the first generations of Baghdadi Jews receiving secular education, a point reflected in the correspondence between Baghdadi Jews and Anglophone Jews well into

\footnotetext{
48 Ibid., 134-145.

49 Ibid., 139.

50 Ibid., 140 cited [AIU archives Irak IE3, report of the committee meeting, 24 December 1872], this appears again in correspondence on 30 December 1890 MS 137 AJ 95/ADD/6.
} 
the mid-1940s: those who received an AIU education presented a strong bias towards writing in French, although they were able to read English. This hybrid way of corresponding is seen in the correspondence between the Anglophone Lawrence and Horace Kadoorie in Shanghai and Hong Kong, and their agent Ibrahim Nahum in Baghdad in the 1930s and 1940s. The AIU-educated Nahum would write in French to his Kadoorie cousins, who would respond in English. ${ }^{51}$ Similar patterns are also apparent in later correspondence with AIU-educated Jews from Baghdad writing to the AJA.

After World War I, the importance of the AIU to the lay council diminished due to several convergent factors. Firstly, other education options became available through the development of Jewish community schools not attached to the AIU (or wilfully separating from the AIU) and the free government schools. ${ }^{52}$ However, this explanation does not fully clarify why the AIU's presence in Baghdad declined, especially when we consider that the AIU continued to send teachers and school administrators to Iraq well into the $1940 \mathrm{~s}$. Furthermore, the main AIU girls' school, Laura Kadoorie, remained the premier girls' school in Baghdad until the 1950s. It is my contention that the distancing from the AIU did not originate from a desire for the Jewish community to remove itself from foreign Jewish organizations, but is instead a question of linguistic and political pragmatism.

As Zvi Yehuda notes, "the AIU pursued its efforts to acculturate the Jews of Mesopotamia in two central spheres: 1) setting the curriculum in community schools, in which the French language was used, and 2) changing the customs and traditions of the students in the spirit of France and the West." ${ }^{53}$ The objectives and the ethnocentrism of the AIU became less attractive in the twentieth century as the position of the French language declined in post-Ottoman Iraq, with English growing in importance even before the Mandate because of increased trade with British controlled India. This shift is apparent in the increasing requests from members of the Baghdad community that English and Arabic be the dominant languages of education. ${ }^{54}$ Officially, the Jewish Community of Baghdad took over management of the AIU schools in the 1920s,

$5^{1} \quad$ The Kadoorie archives in Hong Kong cover correspondence between Baghdad and East Asia in which Ibrahim Nahum, the Kadoorie agent in Baghdad, writes in French and Lawrence and Horace Kadoorie write in English. Although Nahum's date of birth is unknown, it is assumed he attended the AIU school before the Mandate period as he began work for the Kadoories in the early $1920 s$.

$5^{2}$ Yehuda, "Iraqi Jewry," 143, Shiblak, Iraqi Jews, 40.

53 Yehuda, "Iraqi Jewry," 133.

54 Georges Weill, "Les structures et les hommes," in Kaspi, Histore de l'Alliance, 6o; Jewish schools report $1925 \mathrm{MS} 137 \mathrm{AJ} 37 / 4 / 5$. 
becoming responsible for both the financing and the curriculum. The desire was to focus more on Arabic and English. This project was outlined in 1921, but actually took over a decade to achieve due to the complexities involved in overhauling a curriculum and finding suitable teachers. ${ }^{55}$ In practice many of the schools retained aspects of the AIU curriculum and its French bias, focusing on French cultural production, hiring francophone teachers, and working towards French school certificates. ${ }^{56}$ Therefore, although the desire to separate from the AIU is apparent in the correspondence between the AIU, AJA and the lay council, achieving this objective took time and was closely linked to careful diplomacy between all parties involved: the AIU and AJA collaborated in many of their initiatives, and Eastern Baghdadis were influential in both organizations. ${ }^{57}$ Thus, the dominant factor in the shift is the growing relationship between the lay council and the Anglo-Jewish Association, the organization I will discuss in the next section.

Therefore, although the AIU played an important role in developing secular Jewish schools in Baghdad in the nineteenth century, sixty years later it offered little in the way of financial or political assistance in comparison with other actors. The financial assistance offered by the AIU consisted predominantly of funding from Baghdadi Jews based in India and the Far East who had their own agents in Baghdad. In this way they were able to support the community independently of the AIU, or via the AJA if they preferred to work through an organization. As to political support, the French presence in Iraq was considerably less than in other areas of the MENA. Furthermore, the AIU's lack of flexibility in regard to curriculum changes put off the Baghdad elites, who wanted a curriculum adapted to the linguistic needs of the new Iraqi state. ${ }^{58}$ By the 1920 s an English partner to assist the community made more sense than a French one, so that in the first year of the British Mandate in Baghdad the AJA almost completely usurped the position of the AIU as the main foreign organizational partner of the Jewish community in Baghdad. The AJA was to hold this position until the dissolution of the community.

55 Jewish schools report $1925 \mathrm{MS} 137 \mathrm{AJ} 37 / 4 / 5,2-3$.

56 S.R. Goldstein-Sabbah, "Jewish Education in Baghdad: Communal Space vs. Public Spate," in Modernity, Minority, and the Public Sphere:Jews and Christians in the Middle East, edited by S.R. Goldstein-Sabbah and H.L. Murre-van den Berg (Leiden, Netherlands: Brill, 2016), 96-120.

$57 \quad \mathrm{MS}_{137} \mathrm{AJ} 37 / 4 / 2 / 2$, MS $137 \mathrm{AJ} 37 / 4 / 5$.

58 Yehuda, "Iraqi Jewry," 142-143. 
The Anglo-Jewish Association was founded in 1871, originally as a sub-branch of the AIU. ${ }^{59}$ However, it quickly developed its own mandate and ideology, working independently from the AIU in many of its initiatives. This distancing from the AIU is apparent in its official publications in the first half of the twentieth century: it does not mention the AIU in relation to its founding, preferring to stress the idea that it was founded "to aid in promoting the social, moral and intellectual progress of the Jews" and "to obtain protection for those who may suffer in consequence of being Jews." ${ }^{00}$ The two statements point to the position the AJA would take in Baghdad, the social, moral and intellectual progress relating to education, and the protection of those suffering as a consequence of being Jewish, linked to AJA's willingness to act as political intermediary. The first involvement of the AJA in Baghdad, however, was that of supporting the AIU by sending an English teacher to the AIU boys' school in 1879, and agreeing to cover the cost of the teacher's salary. ${ }^{61}$ Shortly afterwards, Silas E. Sassoon presented the AIU with a trust bond of 5,000 rupees to be put toward English instruction, thus assuring the continuation of English at the school and providing funds for the purchase of English-language books for the school library. ${ }^{62}$

In Iraq the AJA became an increasingly important partner of the communal Jewish leadership as the relationship between England and Iraq became stronger upon the establishment of the Mandate. Even before the Mandate, as early as 1890, the AJA minutes note that D. Sassoon in Baghdad had requested that the AJA and the Jewish Board of Deputies in London make inquiries into the new governor general in Baghdad with regard to his attitude towards Jews. ${ }^{63}$ Another important event in the strengthening of relations between the AJA and the lay council was AJA's support of the Jewish community in the controversy over the burial of Rabbi Abdallah Somekh in 1889, when Somekh died during a cholera outbreak. ${ }^{64}$ The issue related to the Jewish community's wishing to bury Somekh by the tomb of Ezekiel. When they were prevented from doing so by the local Arab population, the AJA and Jewish Board of Deputies

59 Zosa Szajkowski, "Conflicts in the Alliance Israelite and the Founding of the Anglo-Jewish Association, the Vienna Allianz, and the Hilfsverein," Jewish Social Studies 19 (1957), 29-30.

6o MS 137 AJ37/4/5 - Ledger of School involvement - Draft Statement of Aims 28th November 1943 .

$61 \quad \mathrm{MS} 137 \mathrm{AJ} 95 / \mathrm{ADD} / 4-14$ May 1879.

62 MS 137 AJ95/ADD/5 - 16 March 1882.

63 MS 137 AJ95/ADD/6 28 January 189o, 11 February 1890.

64 Sassoon Archives Box 35, Jewish National Library, Hebrew University, Jerusalem. 
interceded with the governor of Baghdad on their behalf. 65 Thus, even before the mandate period the AJA showed its willingness to lobby the Ottoman authorities on behalf of the Jews of Baghdad. Therefore, although the AIU remained the dominant foreign figure in Jewish education in Baghdad prior to World War I, the AJA had already proved itself to be the Jewish community's main foreign partner in political matters in the nineteenth century.

The AJA's large role in Baghdad was motivated by two interwoven factors. Firstly, Britain's role in Iraq (mentioned before) is partially to blame for this in fact the only other place that the AJA was as active was Palestine, a point the AJA even refers to in a 1943 summary of its histories and objectives. ${ }^{66}$ Secondly and perhaps more importantly, many Baghdadi Jews on the Indian subcontinent and in East Asia became culturally and linguistically Anglicized, with many eventually gaining British citizenship. ${ }^{67}$ Yet, as mentioned earlier, these Jews continued to feel an obligation towards Iraqi Jewry, with the Anglo-Jewish Association becoming an important channel for this demonstration of solidarity because it also confirmed the 'Britishness' of these Jews.

One important example of an anglicized Baghdadi is Sir Elly Silas Kadoorie (1867-1944). Born in Baghdad, he would spend most of his life outside Iraq in Bombay, Shanghai, and Hong Kong. Kadoorie was an active supporter of many AJA initiatives, but Baghdad held a special place in his philanthropy. In Baghdad the Kadoorie family provided the funds to found several schools (one of which bears the name of Sir Elly's wife Laura Kadoorie) and hospitals (one of which bears the name of his mother Reema) ${ }^{68}$ Kadoorie's attachment to Iraq, and his faith in the work of the AJA and in the future of Britain in the Middle East were so great that he set up a residuary trust in 1924 allocating one third of his fortune to building schools in Mesopotamia and Palestine, and one third to the AJA to be used for the purpose of education. ${ }^{69}$ After Sir Elly's death his sons Horace and Lawrence continued this tradition by supporting the Jewish institutions in Baghdad - they retained their father's agent in Baghdad to run philanthropic initiatives, thus ensuring the AJA's role in Baghdad until the early 1950s. The Sassoon family was also active in the AJA. Ellis Franklin (a mem-

65 MS 137 AJ95/ADD/6 22 October 1889 11, February 1890.

66 MS 137 AJ37/4/5 - Ledger of School involvement - Draft Statement of Aims 28 November 1943 .

67 For a discussion of the Baghdadi Jews' becoming Anglicized, see the volumes mentioned above by Roland, Meyer, and Cernea. This process of Anglicization provides an interesting contrast to the Baghdadi process of Arabization which occurred in Iraq, and is a point which deserves greater academic attention and discussion.

68 MS 137 AJ31/14/2/1 - 15 June 1923.

69 The final third was left to his brother, Eleazar Kadoorie - MS 137 AJ31/3/2/1 1924-43 1 of 3. 
ber of the Baghdadi Sassoon family), for instance, held the role of treasurer, ${ }^{70}$ and as stated earlier many of the first trusts and scholarships from the AJA for Baghdad were endowed by members of the Sassoon family.

This Eastern Baghdadi bridge between Baghdad and London acted as a diplomatic intermediary in the perpetually sensitive issue of finances and fundraising. One recurring source of tension was the lay committee's directly soliciting donations from co-religionists in England for their philanthropic work in Baghdad. Numerous letters between the AJA and the lay council show the AJA suggesting that the lay council restrict its fundraising to Iraq so as to avoid overlapping efforts. ${ }^{71}$ These exchanges suggest that the AJA, which depended on private donations for its charitable works, saw the Baghdadis in Baghdad not only as a partner but also as a competitor in raising money. Such conflicts over 'fundraising territory' were often assuaged by Baghdadis residing outside Iraq. These exchanges also suggest a constant theme of the lay council working to assert its independence and to be viewed as a partner rather than a simple aid recipient.

The two most important factors which attracted the lay council in Baghdad to working with the AJA were the inclination to support the community politically, mentioned earlier, and the desire for English-language education in the Jewish schools. Although prior to the 1920 the Jewish schools flourished like no other in Baghdad, the French curriculum, as already stated, left something to be desired in the eyes of the Baghdadis, who saw their future as wedded to Arabic and English. The watershed moment in the shifting of the curriculum from the AIU system to a hybrid Iraqi/British system was achieved in the 1920s, when the AJA arranged for the Jewish community to have Lionel Smith act unofficially as director of the Jewish schools. Smith was the British advisor to the Ministry of Education from 1923-1931. Later writings by him suggest serious frustration in working with the Iraqi government when he felt his suggestions fell on deaf ears, which perhaps explains his willingness to dedicate so much time to the Jewish community. ${ }^{72}$ Smith was charged with assisting the lay council and schools' committee in reorganizing and improving the Jewish school system. ${ }^{73}$ Originally, the AJA offered to pay Smith 600 pounds per year

\footnotetext{
$70 \quad$ Kaspi, Histoire de L'Alliance, 56.

71 http://www.ija.archives.gov/viewer/2994/19579. This file contains correspondence in English, French, and Arabic between the AJA, AIU, and the various Baghdadi committees involved in fundraising for schools between 1924-1935.

72 E.C. Hodgkin, "Lionel Smith on Education in Iraq," Middle Eastern Studies 19,2 (1983): 253-260.

73 MS 137 AJ37/4/2/2 - 24 March 1926.
} 
to be at the disposal of the Jewish community. ${ }^{74}$ Smith declined the money, preferring to advise on an unofficial level because he did not want his work being brought to the attention of the government. ${ }^{75}$ Although Smith writes of troubles in Jewish education, such as teachers resisting additional training, ${ }^{76}$ his correspondence with the AJA and the Lay council presents him as having a positive role in professionalizing teaching and updating the curriculum. ${ }^{77}$ This type of assistance, in which a British colonial official unofficially worked for the Jewish community, would have been impossible without the connections the AJA was able (and willing) to provide.

The high value placed on English language education by the communal leadership is further demonstrated by the founding of the Shamash school in 1928, the first school to use a largely British curriculum. This school was to usurp the place of the AIU Albert Sassoon boys' school as the most prestigious Jewish school in the city. The Shamash school was heavily supported by the AJA, which supplied both teachers and administrators and provided an annual subvention to cover administrative costs. Ironically, the person who set up the endowment for the school, Benjamin Shamash, was a Baghdadi Jew residing in Nice, France, and a graduate of the AIU school in Baghdad. ${ }^{78}$ Thus, his desire to establish an English-language Jewish school in Baghdad and the support and thanks he received from the lay council are a testament to this preference of English over French.

The positions of the AJA, the Eastern Baghdadis, and Jewish community of Baghdad in regard to financial assistance and education are best summarized in a letter sent by the president of the AJA Claude Montefiore to Sir Elly Kadoorie on 17 May 1932. The letter is a response to Kadoorie questioning the level of engagement of the AJA and the level of English being taught in Baghdad for which Kadoorie was deeply concerned. Montefiore in his response states that:

For boys ... good knowledge of English is essential. The AJA in realization of this helps as far as its means allow, the Shamash school, which is designed to give Baghdad boys a secondary education in English. The present policy of the AJA in this regard is apparently appreciated by Baghdadis in England and elsewhere, for they have entrusted more than

$74 \quad$ MS 137 AJ37/4/2/2 - 26 October 1925.

75 MS $137 \mathrm{AJ}_{37 / 4 / 2 / 2}-14$ December 1925 .

$76 \quad$ MS 137 AJ37/4/2/2 - 26 April 1926.

77 MS 137 AJ37/14/2/1, School committee correspondence 1921-1926.

$78 \quad$ MS 137 AJ 37 3/2/2. 
3,000 pounds within the last year or two, earmarked for the Shamash school. ${ }^{79}$

Although the majority of the AJA staff was successively recalled in the late 1930s, firstly due to the growing political instability in Iraq and later due to World War II, the AJA continued to work with the lay council in Baghdad up until the dismantling of the community between $1949-1951 .^{80}$ In 1936 , for example, they lobbied the British Foreign Office, asking it to intercede with the Iraqi government to lift a ban on certain Jewish periodicals coming into the country. ${ }^{81}$ Even after wwII they continued to help to direct funds to the Jewish schools, whenever possible trying to arrange for teachers for the schools. Finally, in the period between 1947-1951 the AJA, assisted by the British government, monitored the deteriorating position of the Jewish community in Iraq and worked with the American Jewish JDC to ultimately get the Jewish community out of Iraq. ${ }^{82}$

\section{5}

\section{Conclusion}

The relationship between the Jews in Baghdad and European Jewry was a product of nineteenth-century European Jewish interest in MENA Jewry which fundamentally changed the way in which disparate Jewish communities interacted with and supported each other, and in turn changed the position of Jews throughout MENA. Unlike other areas of MENA, where Christian missionary initiatives competed with Jewish schools, in Baghdad the Jewish schools pre-dated the arrival of Christian missionary schools by almost half a century. Therefore, also unlike other areas of MENA, Christian missionizing was not a concern for the Jews in Baghdad. Furthermore, because the local Christian population was significantly smaller than the Jewish population there are no traces of the competition between transnational Jewish and Christian bodies as found in some other cities of the Levant. In fact, many Christian and Muslim elites in Baghdad sent their children to the schools of the Jewish community until in the Mandate period other options became available. ${ }^{83}$ For this reason

\footnotetext{
79 MS 137 AJ37/4/2/2 - 17 May 1932.

8o $\quad$ MS 137 AJ37 6/1/4 - Foreign affairs committee progress report April 21, $195^{\circ}$.

81 Goldstein-Sabbah, "Censorship and the Jews of Baghdad."

$82 \quad \mathrm{MS}_{137} \mathrm{AJ} 37$ 6/1/3, MS137 AJ37 6/1/3 f.2.

83 Roderic D. Matthews and Matta Akrawi, Education in Arab Countries of the Near East: Egypt, Iraq, Palestine, Transjordan, Syria, Lebanon (Washington, DC: American Council on Education, 1949), 209-213.
} 
the decisions of the Jewish communal leadership pertaining to education had an influence that extended beyond the Jewish community in Baghdad. Furthermore, although the initial relationship between foreign Jews and Baghdad was driven by European Jews living in Baghdad and the foreign consuls there, by the Mandate period the Baghdadis themselves were the key decision makers and their decisions were based on their position as Iraqi citizens.

Comparing the philosophies, actions, and initiatives of the two organizations and their relationships with the lay council makes it possible to understand why from the 1920s onwards the Jews in Baghdad opted to strengthen their ties to AJA and distance themselves from the AIU. In my opinion the foremost reason was linguistic, specifically the fact that with the onset of the Mandate period English was becoming the most important language in Iraq after Arabic. Therefore, for Jews in Baghdad it was more advantageous to partner with an organization tied to the British Empire than one from the Francophone sphere. This point is most clearly illustrated by the Jewish Community hiring Lionel Smith to expand and improve the entire the Jewish school system, thus signalling a clear break with the AIU. Of course, these relationships were not mutually exclusive; in fact, the lay council worked with many foreign Jewish groups around the world in the first half of the twentieth century. The AIU continued to support their schools in Baghdad by providing curricula and teachers up until the 1950 os. $^{84}$ However, unlike the AJA they did not become involved in political advocacy - the AJA, for instance, lobbied the Foreign Office to lift the censorship of Jewish newspapers in Baghdad in the 1930s. ${ }^{85}$

By comparing the working mode of the AJA to that of the AIU we clearly see that the AJA was less intellectually wedded to the propagation of British culture than the AIU was to French culture. Whereas the AIU was a staunch proponent of the teaching of French as the dominant language in their schools, the AJA saw greater value in a strong programme in Arabic - a point that was commensurate with the ideology of the communal leadership. The AJA also showed greater enthusiasm and flexibility in working with the local Iraqi curriculum than the AIU. ${ }^{86}$ The lay council also preferred the AJA over the AIU as their main partner, because they were willing to involve themselves in public health and political issues concerning the community, whereas the AIU generally limited itself to education. A factor further solidifying this Anglo-Baghdadi

$84 \quad \mathrm{MS}_{137} \mathrm{AJ} 37 / 3 / 3 / 8$.

85 Goldstein-Sabbah, "Censorship and the Jews of Baghdad."

86 This led to the hiring of Adolph Brotman in 1926, an Orthodox Jew with a wife and child, who accompanied him to Baghdad. MS 37 AJ37/4/2/2. Communications from 3 March 1926 to 18 September 1934. 
relationship was that the Iraqi Jewish Diaspora for the most part, resided in places under British colonial control or Britain itself, and facilitated a close cooperation between the two bodies. Finally, the language choices of the Jewish communal leadership demonstrate not only their agency within Jewish networks, but also their desire to integrate within the greater Iraqi society. This is exemplified by the early requests that school curricula place greater emphasis on the Arabic.

In conclusion, the Jewish communal leadership of Baghdad consistently sought cooperation with foreign Jewish organizations up until the 1950s, to strengthen their position within Iraqi society through the development of a modern Jewish communal infrastructure. The Jewish community in Baghdad's multi-decade relationship with these organizations and the correspondence which remains suggest that the Jewish communal leadership saw themselves as part of a global Jewish community - an idea which was thought to be fully compatible with being an invested Iraqi citizen. ${ }^{87}$ Thus, the choice on the part of the Jewish leadership in Baghdad to align itself with the AJA as opposed to the AIU was a strong act of communal independence, driven by political calculation and linguistic pragmatism, to assure their integration into the fledgling Iraqi state.

\section{Bibliography}

\section{Archival Documents}

Alliance Israélite Universelle (AIU)

Bulletin de l'Alliance 1864, p. 4.

AIU archives Bobin 4 fiche 8-9.

AIU archives Irak IE3.

American Jewish Joint Distribution Committee (JDC)

JDC/NY/AR1921/ooo16/NY/AR1921/00773.

JDC/NY/AR1418/00003/NY/AR1418/03503.

Anglo-Jewish Association (AJ)

MS $137 \mathrm{AJ}_{31 / 3} / 2 / 11 / 3$.

MS $137 \mathrm{AJ} 37$ 6/1/3.

MS 137 AJ37 6/1/3 f.2.

MS 137 AJ37 3/2/2.

MS $137 \mathrm{AJ} 37 / 3 / 3 / 8$.

87 Jewish schools report 1925 MS 137 AJ37/4/5, Jewish schools reports 1930 CAHJP Iraq File $\mathrm{P}_{3} / 2464$. 


$$
\begin{aligned}
& \text { MS } 137 \text { AJ37/4/2/2. } \\
& \text { MS }{ }_{137} \text { AJ37/4/5. } \\
& \text { MS } 137 \text { AJ37 6/1/4. } \\
& \text { MS } 137 \text { AJ37/14/2/1. } \\
& \text { MS } 137 \text { AJ95/ADD/4. } \\
& \text { MS } 137 \text { AJ95/ADD/5. } \\
& \text { MS } 137 \text { AJ95/ADD/6. }
\end{aligned}
$$

Central Archive for the History of the Jewish People (CAHJP)

CAHJP Iraq File $\mathrm{P}_{3} / 2464$.

India Office London (IOL)

Indian Office Library, British Library IOR/L/PS/11/139 P 4484/1918.

Iraqi Jewish Archives (IJA)

http://www.ija.archives.gov/viewer/2994/19579.

Jewish National Library, Hebrew University, Jerusalem

Sassoon Archives Box 35.

\section{Other Sources}

Agassi, Eliyahu and Avraham Ben-Yaakov. "Chapter Nine: Communal Administration and Institutions," in Annals of Iraqi Jewry, edited by Ora Melamed. Jerusalem: Eliner Library, 1995 .

Ayalon, Yaron. "Baghdad." In Encyclopedia of Jews in the Islamic World Vol. I, Executive Editor Norman A. Stillman. Leiden: Brill 2010.

Bashkin, Orit. "Why did Baghdadi Jews Stop writing to their brethren in Mainz?." In Histories of Printing and Publishing in the Languages and Countries of the Middle East, edited by Philip Sadgrove, Journal of Semitic Studies Supplement 15 (2005): 95-110.

Bashkin, Orit. New Babylonians: A History of Jews in Modern Iraq. Stanford: Stanford University Press, 2012.

Battatu, Hana. The Old Social Classes and the Revolutionary Movement of Iraq: A Study of Iraq's Old Landed and Commercial Classes and of its Communists, Bathists, and Free Officers. Princeton, NJ: Princeton University Press, 1978.

Bauer, Yehuda. My Brother's Keeper: A history of the American Joint Distribution Committee 1929-1939. Philadelphia: Jewish Publication Society of America, 1974.

Betta, Chara. "From Orientals to Imagined Britons: Baghdadi Jews in Shanghai." Modern Asian Studies 37,4 (2003): 999-1023.

Bieder, Joan. The Jews of Singapore. Singapore: Suntree, 2007.

Blanc, Haim. Communal Dialects in Baghdad. Cambridge: Harvard University Press, 1964.

Cernea, Ruth Fredman. Almost Englishmen: Baghdadi Jews in British Burma. New York: Lexington Books, 2007. 
Frankel, Jonathan. The Damascus Affair: 'Ritual Murder,' Politics, and the Jews in 1840. Cambridge: Cambridge University Press, 1997.

Goldberg, Harvey E. Sephardi and Middle Eastern Jewries: History and Culture in the Modern Era. Bloomington: Indiana University Press, 1996.

Goldstein-Sabbah, Sasha. "Censorship and the Jews of Baghdad: Reading between the lines in the case of E. Levy." The Journal of the Middle East and Africa 7,3 (2016): 283-300, 2016. DOI: 10.1080/21520844.2016.1227927.

Goldstein-Sabbah. S.R. "Jewish Education in Baghdad: Communal Space vs. Public Space," in Modernity, Minority, and the Public Sphere: Jews and Christians in the Middle East, edited by S.R. Goldstein-Sabbah and H.L. Murre-van den Berg, 96-120. Leiden: Brill, 2016.

Goldstein-Sabbah, Sasha Rachel. "Baghdadi Jewish Networks in Hashemite Iraq:Jewish Transnationalism in the Age of Nationalism." PhD diss., Leiden University, 2019.

Green, Abigail and Vincent Viaene, eds. Religious Internationals in the Modern World: Globalization and Faith Communities since 1750. Basingstoke: Palgrave Macmillan, 2012.

Hakak, Lev. The Emergence of Modern Hebrew Creativity in Babylon, 1735-1950. West Lafayette: Purdue University Press, 2009.

Hodgkin, E.C. "Lionel Smith on Education in Iraq." Middle Eastern Studies 19,2 (1983): 253-260.

Kaspi, André, ed. Histoire de l'Alliance Israélite Universelle de 1860 a nos jours. Paris: Armand Colin, 2010.

Kattan, Naim. Farewell Babylon: Coming of Age in Jewish Baghdad. London: Souvenirs Press, 2005.

Lehmann, Matthias. Emissaries from the Holy Land: The Sephardic Diaspora and the Practice of Pan-Judaism in the Eighteenth Century. Stanford: Stanford University Press, 2014.

Meyer, Maisie J. From the Rivers of Babylon to the Whangpoo: A Century of Sephardi Jewish Life in Shanghai. New York: University Press of America, 2003.

Musleah, Ezekiel. On the Banks of the Ganga: The Sojourn of Jews in Calcutta. North Quincy MA: The Christopher Publishing Company, 1975.

Pelli, Moshe. Haskalah and Beyond: The Reception of the Hebrew Enlightenment and the Emergence of Haskalah Judaism. Lanham: University Press of America, 2010.

Roland, Joan. The Jewish Communities of India: Identity in a Colonial Era. London: Transaction Publishers, 1998.

Sawdayee, MauriceM.TheBaghdadConnection.LocustValley, NY:MauriceM.Sawdayee, 1991.

Schlaepfer, Aline. Les intellectuels juifs de Bagdad: Discours et allégeances (1908-1951), Christians and Jews in Muslim Societies series. Leiden: Brill, 2016. 
Şeni, Nora. Les inventeurs de la philanthropie juive. Paris: Éditions de La Martinière, 2005 .

Shiblak, Abbas. Iraqi Jews: A History of Mass Exodus. London: Saqi Books, 2005.

Silliman, Jael. Jewish Portraits Indian Frames: Women's Narratives from a Diaspora of Hope. Lebanon: University Press of New England, 2001.

Sluglett, Peter. Britain in Iraqi: Contriving King and Country. London: I.B. Tauris, 2017.

Stillman, Norman A. Jews of Arab Lands in Modern Times. Philadelphia: JPS, 1991.

Szajkowski, Zosa. "Conflicts in the Alliance Israelite and the Founding of the Anglo-Jewish Association, the Vienna Allianz, and the Hilfsverein." Jewish Social Studies 19 (1957): 29-30. 